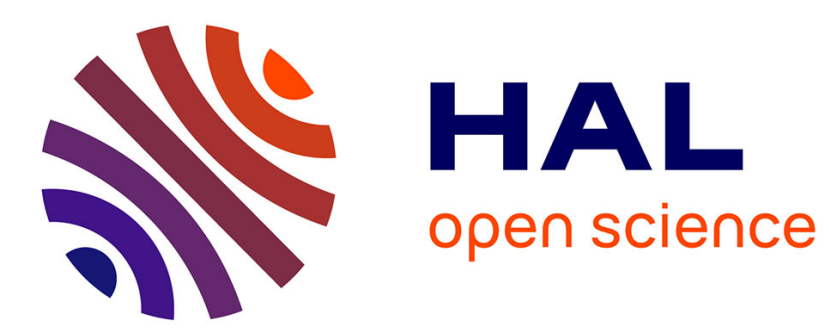

\title{
Influence of crop management on sunflower stem canker (Diaporthe helianthi)
}

Philippe Debaeke, André Estragnat, Raymond Reau

\section{To cite this version:}

Philippe Debaeke, André Estragnat, Raymond Reau. Influence of crop management on sunflower stem canker (Diaporthe helianthi). Agronomie, 2003, 23 (7), pp.581-592. 10.1051/agro:2003032 . hal-00886210

\section{HAL Id: hal-00886210 https://hal.science/hal-00886210}

Submitted on 1 Jan 2003

HAL is a multi-disciplinary open access archive for the deposit and dissemination of scientific research documents, whether they are published or not. The documents may come from teaching and research institutions in France or abroad, or from public or private research centers.
L'archive ouverte pluridisciplinaire HAL, est destinée au dépôt et à la diffusion de documents scientifiques de niveau recherche, publiés ou non, émanant des établissements d'enseignement et de recherche français ou étrangers, des laboratoires publics ou privés. 


\title{
Influence of crop management on sunflower stem canker (Diaporthe helianthi)
}

\author{
Philippe DebaeKE ${ }^{a *}$, André Estragnat ${ }^{\mathrm{b}}$, Raymond ReAU ${ }^{\mathrm{c}}$ \\ ${ }^{a}$ INRA, Unité d'Agronomie, BP 27, 31326 Castanet-Tolosan Cedex, France \\ ${ }^{\mathrm{b}}$ Cetiom, Zone Sud, Ferme En Crambade, 31450 Montesquieu-Lauragais, France \\ ${ }^{\mathrm{c}}$ Cetiom, Centre de Grignon, BP 4, 78850 Thiverval-Grignon, France
}

(Received 22 March 2002; accepted 26 February 2003)

\begin{abstract}
Sunflower stem canker (phomopsis) is a fungal disease caused by Diaporthe helianthi Munt.-Cvet. et al. which is responsible for yield losses of up to 40\%. A programme was carried out by INRA and Cetiom in Southwestern France (1994-2000) to analyze the effects of sunflower crop management on the frequency and severity of phomopsis. The proportion of stems infected by D.helianthi always increased with stem density while the effects of nitrogen supply were less clear-cut. Delayed sowing significantly reduced leaf and stem infection. Crop management systems were evaluated over 7 years: the reduction in plant density and $\mathrm{N}$ supply was not sufficient to lower the infection rate to the level given by fungicides, but in conjunction with delayed sowing, infection levels were comparable with early and protected sowings. Fungicide-free, low-input management was profitable provided that tolerant genotypes were used. Heavy rain in late spring limited the efficacy of cultural methods.
\end{abstract}

sunflower stem canker / Diaporthe helianthi / sunflower (Helianthus annuus L.) / N fertilization / crop density

Résumé - Influence de la conduite de culture du tournesol sur les attaques de phomopsis (Diaporthe helianthi). Le phomopsis du tournesol, maladie cryptogamique causée par Diaporthe helianthi Munt.-Cvet. et al., est responsable de pertes de rendement pouvant atteindre $40 \%$. Au travers d'une collaboration INRA-Cetiom (1994-2000), les effets de la conduite de culture du tournesol sur la fréquence et la gravité des attaques de phomopsis ont été étudiés expérimentalement dans la région toulousaine. Il a été montré que la densité de peuplement augmente la proportion de tiges présentant des taches de phomopsis. Par contre, l'augmentation des doses d'azote peut se traduire dans certaines conditions par une diminution de la fréquence de tiges attaquées. Le retard de semis réduit le risque de contamination foliaire et de dégât sur tige. Des conduites intégrant ces techniques ont été évaluées pendant 7 années : si la stratégie de rationnement végétatif (réduction de la densité de peuplement et de la fertilisation azotée) n'est pas suffisante à elle seule pour maîtriser le phomopsis, son association avec le semis tardif permet d'atteindre des niveaux d'attaque proches de ceux obtenus en semis précoce, protégés chimiquement. La rentabilité des conduites «bas intrants », ne recevant pas de fongicides, n'est assurée que si l'on utilise des variétés peu à très peu sensibles et en l'absence de forte hygrométrie en juin.

phomopsis / Diaporthe helianthi / tournesol (Helianthus annuus L.) / fertilisation azotée / densité de peuplement

\section{INTRODUCTION}

During the 80s the French sunflower (Helianthus annuus L.) area increased twenty-fold, with prices which were very favorable to oil-protein crops and caused sunflower to feature frequently in the crop rotation [6]. One of the main agronomic consequences was an explosion of cryptogamic diseases and the build-up of soil inoculum. Sunflower stem canker, also known as phomopsis, is a fungal disease caused by Diaporthe helianthi Munt.-Cvet. et al. (asexual stage Phomopsis helianthi) [28]. It appeared in Southwestern France in 1984 and spread from 1992-93 to other main areas of sunflower production (Centre and Poitou-Charentes) [13].
The main aspects of fungus epidemiology have been thoroughly described by numerous authors $[2,16,20,26,29,30$, $32]$. Ascospores are actively released from perithecia maturing on the sunflower debris and are spread by wind and rain splash throughout the growing season. Leaves are infected at the margin and the mycelium progresses along the veins and down the petiole until it reaches the stem, where an elongated grey brown lesion is formed, always centered on axils. Relative humidity of $90 \%$ must be maintained for $10-12 \mathrm{~h}$ for leaf infection to be successful. On average, leaf spots are visible 20 days after spore deposition for air temperatures ranging from 20 to $24^{\circ} \mathrm{C}$ and yield loss is related to the severity of attacks on stems (girdling lesions). Yield losses exceeding 
$40 \%$ were commonly observed, resulting from early senescence, plant wilting and stem breakage in unprotected conditions or after very early infections $[13,26]$. The oil content may also be reduced by $15-25 \%[1,17,32]$.

The use of tolerant genotypes is a good way of reducing stem canker damage [35]. However, this means of control is not available for the entire production area because issues such as productivity, oil concentration and composition, duration of crop growth and tolerance to the various races of mildew (Plasmopara halstedii) may not be associated with tolerance to Phomopsis. Recently, in regions where the disease has been endemic for 20 years, such as Yugoslavia, Masirevic and Forgic [27] observed an erosion of tolerance in the face of heavy infections.

In regions where Phomopsis is normally present, a fungicide treatment at the critical plant height for conventional sprayers $(50-70 \mathrm{~cm})$ or following the advice of the official Plant Protection Service is generally recommended even when using tolerant genotypes $[14,31]$. The European proposals for the reduction of chemicals in agriculture and the trend towards the use of moderately tolerant genotypes could promote the use of additional measures based on crop management.

The agronomic principles are relatively well known (at least qualitatively) [20, 21, 23, 26]: (1) prophylactic methods such as deep burial of harvest residues or the observation of a minimum interval of 3-4 years between successive sunflower crops in order to limit the soil inoculum; (2) "escape" strategies such as delayed sowing, to synchronize the most susceptible periods (bud formation) with low-rainfall periods, and (3) creating conditions less favorable to the expression of and damage by the pathogen through the limitation of leaf area or 'rationing' (reduced stem density and $\mathrm{N}$ fertilization, increased row width), efficient weed control, reduction in water applications and non-limiting $\mathrm{K}$ nutrition. The main challenge is to prevent an excessive development of the sunflower canopy by a suitable choice of sowing date, plant population, $\mathrm{N}$ fertilization and genotype, without seriously restricting the yield potential.

A cooperative study was carried out by INRA and Cetiom to characterize and evaluate the effects of sunflower crop management on the occurrence and severity of Phomopsis attacks. This paper reports the main results obtained over 7 years at 2 experimental locations near Toulouse (SW France), where the disease first appeared in 1984 and where it is regularly present in spite of the repeated use of tolerant genotypes.

\section{MATERIALS AND METHODS}

The two experimental locations near Toulouse (SW France) were Auzeville (INRA) and En Crambade (Cetiom). The two sites are similar in terms of both weather and soil conditions. The soil is deep, alluvial, with a silty-clay to clay texture, which may induce early and rapid crop growth provided water and $\mathrm{N}$ conditions are not limiting.

Factorial experiments were carried out over 4 years (19972000) at INRA and Cetiom experimental farms to isolate the effects of single factors, such as sowing date, genotype, crop density, $\mathrm{N}$ fertilization, water regime and fungicide protection on the occurrence and severity of stem canker.
Table I. Susceptibility of the sunflower cultivars to Phomopsis.

\begin{tabular}{lccc}
\hline Susceptible (S) & $\begin{array}{c}\text { Moderately } \\
\text { Susceptible (MS) }\end{array}$ & Tolerant (T) & Resistant (R) \\
\hline DK 3790 & Albena & AllStar & Asturia \\
LG 5410 & Melody & Inedi & \\
Olbaril & & Labrador & \\
Proleic 204 & & LG 5830 & \\
& & Santiago & \\
& & Select & \\
\hline
\end{tabular}

Crop management systems were tested at Auzeville from 1994 to 2000 and at En Crambade from 1994 to 1996 to evaluate integrated methods of disease control combining the various cultural methods. The main objective was to evaluate the ability of low-input systems to control the disease by nonchemical methods without loss of profit.

A wide range of cultivars (13), differing by their intrinsic susceptibility to Phomopsis [35], were used in the experiments (Tab. I). The cultivars are referred to as susceptible (S), moderately susceptible (MS), tolerant (T) and resistant (R).

Most of the experiments were carried out under natural conditions of pathogen infection. Semi-natural conditions of infection were created in 1996 (Cetiom-96), 1999 (Cetiom99I) and 2000 (Cetiom-00, INRA-00I) by placing fragments of infected sunflower stalks regularly throughout the plot at the star bud stage in order to increase and homogenize the inoculum level within the crop [37]. Frequent sprinkler irrigation was applied to stimulate the infection process.

As Phoma black stem (Phoma macdonaldii), a pathogen competing with Phomopsis for stem infection, has increased during the last few years in SW France, mancozeb (Dithane DG, $2.5 \mathrm{~kg} / \mathrm{ha}$ ) was applied in 1999 and 2000 at the 10-12 leaf and at the star bud stage to selectively prevent the development of Phoma.

\subsection{Factorial trials}

The details of the 9 factorial trials (experimental design, cultivars and crop management factors) are presented in Table II. Plot size ranged from 30 to $60 \mathrm{~m}^{2}$ (Cetiom) and from 90 to $180 \mathrm{~m}^{2}$ (INRA) in the factorial experiments, except INRA-97 and INRA-98, which were conducted on small plots $\left(15 \mathrm{~m}^{2}\right)$. The factorial experiments were randomized 4-block designs, except INRA-99 and INRA-00 (H and I), which were not replicated.

The effect of crop density was studied in 9 experiments by comparing 2 levels (Cetiom-94, Cetiom-99S, Cetiom-99I, Cetiom-00, INRA-99, INRA-00I and INRA-00H) or 3 levels (INRA-97 and INRA-98) of density. The effect of N fertilization was studied in 7 experiments by applications at 2 levels (Cetiom-94, Cetiom-99S, Cetiom-99I, Cetiom-00, INRA-00H and INRA-00I) or 4 levels (INRA-99) of nitrogen. Generally, the full rate of $\mathrm{N}$ fertilizer was applied at sowing except in 2000 (INRA-00) where the amount was split between sowing and the 12-leaf stage.

Where susceptible and tolerant genotypes were grown in the same experiment, an evaluation of the effect of genotypic variation on epidemiology was made (Cetiom-94, Cetiom-99S, Cetiom-99I, Cetiom-00, INRA-99, INRA-00H and INRA-00I). 
Table II. Main characteristics of the factorial trials carried out at INRA and Cetiom from 1997 to 2000.

\begin{tabular}{|c|c|c|c|c|c|c|c|c|c|}
\hline Exp. & Design & Year & Cultivar(s) & Sowing date & $\begin{array}{l}\text { Stalk } \\
\text { residue }\end{array}$ & $\begin{array}{l}\text { Plant density } \\
\mathrm{pl} \cdot \mathrm{m}^{-2}\end{array}$ & $\begin{array}{c}\mathrm{N} \text {-fertilizer } \\
\mathrm{kg} \cdot \mathrm{ha}^{-1}\end{array}$ & $\begin{array}{l}\text { Irrigation } \\
\mathrm{mm} \cdot \mathrm{ha}^{-1}\end{array}$ & $\begin{array}{c}\text { Fungicide } \\
\text { (application date) }\end{array}$ \\
\hline INRA-97 & $\begin{array}{c}3 \text { factors } \\
\text { randomized 4-blocks }\end{array}$ & 1997 & $\begin{array}{c}\text { Albena, Labrador, } \\
\text { Melody }\end{array}$ & 10 April & No & $3.7-6.2-9.0$ & 90 & $0-100$ & No \\
\hline INRA-98 & $\begin{array}{c}3 \text { factors } \\
\text { randomized 4-blocks }\end{array}$ & 1998 & $\begin{array}{c}\text { Albena, Labrador, } \\
\text { Melody }\end{array}$ & 9 April & No & $3.7-6.2-9.0$ & 90 & $0-130$ & No \\
\hline INRA-99 & $\begin{array}{l}\text { split-plot } 3 \text { factors } \\
\text { unreplicated } \\
\text { main plot: nitrogen }\end{array}$ & 1999 & $\begin{array}{c}\text { Labrador, Olbaril, } \\
\text { Santiago }\end{array}$ & 1 April & No & $5.1-7.0$ & $0-30-60-120$ & $0-120$ & No \\
\hline INRA-00H & $\begin{array}{l}\text { split-plot } 4 \text { factors } \\
\text { unreplicated } \\
\text { main plot: irrigation }\end{array}$ & 2000 & $\begin{array}{l}\text { AllStar, DK3790, } \\
\text { Inedi, Olbaril, } \\
\text { Proleic 204, } \\
\text { Santiago }\end{array}$ & 10 April & No & $5.0-8.0$ & $0-120$ & $0-35-85$ & No \\
\hline INRA-00I & $\begin{array}{c}\text { split-plot } 4 \text { factors } \\
\text { unreplicated } \\
\text { main plot: irrigation }\end{array}$ & 2000 & $\begin{array}{l}\text { AllStar, DK3790, } \\
\text { Inedi, Olbaril, } \\
\text { Proleic 204, } \\
\text { Santiago }\end{array}$ & 10 April & Yes $^{1}$ & $5.0-8.0$ & $0-120$ & $0-35-85$ & $\mathrm{No}^{3}$ \\
\hline Cetiom-96 & $\begin{array}{c}2 \text { factors } \\
\text { randomized 4-blocks }\end{array}$ & 1996 & LG 5830 & $\begin{array}{c}1 \text { April (D1) } \\
30 \text { April } \\
\text { (D2) }\end{array}$ & $\begin{array}{c}\text { Yes } \\
\text { (31 May) }\end{array}$ & 6.6 & 60 & 75 & $\begin{array}{c}\text { No } \\
7 \text { June }^{2} \text { (D1) } \\
\text { 18 June } \\
\text { (D2) }\end{array}$ \\
\hline Cetiom-99S & $\begin{array}{c}3 \text { factors } \\
\text { randomized 4-blocks }\end{array}$ & 1999 & Santiago, Olbaril & 12 April & No & $5.0-8.0$ & $0-120$ & 0 & $\mathrm{No}^{3}$ \\
\hline Cetiom-99I & $\begin{array}{c}3 \text { factors } \\
\text { randomized 4-blocks }\end{array}$ & 1999 & Santiago, Olbaril & 6 April & $\begin{array}{c}\text { Yes } \\
\text { (28 May) }\end{array}$ & $5.0-8.0$ & $0-120$ & 120 & $\mathrm{No}^{3}$ \\
\hline Cetiom-00 & $\begin{array}{c}3 \text { factors } \\
\text { randomized 4-blocks }\end{array}$ & 2000 & Santiago, Olbaril & 7 April & $\begin{array}{c}\text { Yes } \\
\text { (15 May) }\end{array}$ & $5.0-8.0$ & $0-120$ & 30 & $\mathrm{No}^{3}$ \\
\hline
\end{tabular}

${ }_{2}^{1}$ Introduction of infected sunflower stalks on 5 June, removal on 15 June.

${ }^{2}$ Corvet Flo (fenpropimorph + mancozeb + carbendazim) $2.51 \cdot$ ha $^{-1}$.

3 Application of Dithane DG (mancozeb) $2.5 \mathrm{~kg} \cdot \mathrm{ha}^{-1}$ to control selectively Phoma black stem.

The influence of inoculum amount was evaluated by comparing the different weather patterns and especially the rainfall amount from mid-May to the end of June. In 2000, the influence of infected sunflower debris placed between the rows was analyzed by comparing the results of INRA-OOH and INRA-00I. Once leaves are infected, climatic conditions such as high temperatures or low rainfall may hinder the appearance and extension of stem lesions. In 2000, 3 levels of sprinkler irrigation after leaf infection (Irr1: 0; Irr2: $35 \mathrm{~mm}$ on 23 June; Irr3: $35 \mathrm{~mm}$ on 23 June $+35 \mathrm{~mm}$ on 7 July) were compared in both the INRA-00H and INRA-00I experiments.

The opportunity to reduce Phomopsis infection by significantly delaying the sowing date was evaluated only in 1996 (Cetiom-96). The response to a single fungicide application to control Phomopsis was evaluated during 3 successive years in Cetiom experiments using factorial trials (1996) (Tab. II) and crop management systems experiments (1994 and 1995) (Tab. III).

\subsection{Crop management systems experiments}

Combination of individual factors resulted in crop management systems (Tab. III) that were evaluated in 4 experiments (INRA-94, Cetiom-94, Cetiom-95 and ICS 95-00). Management options were defined as high-input (HI), medium-input (MI) or low-input (LI) according to $\mathrm{N}$ fertilizer rates and crop densities increasing from LI to HI. Experiments were irrigated (_irr) or not (_rfd for rainfed). All experiments were conducted under conditions of natural disease infection and without selective chemical protection against Phoma black stem.

INRA-94. The 5 management systems varied in plant density (2 levels), $\mathrm{N}$ fertilization (3 levels), irrigation (3 levels) and fungicide (sprayed or not). The cultivar Select (T) was sown on 72 plots of $550 \mathrm{~m}^{2}$ after a cropping system experiment which resulted in a wide variation of initial soil mineral nitrogen among plots and, consequently, of expected leaf area index at anthesis [5,7]. The management systems were assigned randomly to the plots and the number of replications was different for each system: 6 (HI_irr), 6 (MI_irr), 14 (HI_rfd), 20 (LI_rfd) and 26 (MI_rfd).

CETIOM $(94,95)$. In 1994, the 7 crop management systems, arranged in a randomized 4-block design, were defined as follows: (a) high crop density $\left(6.5\right.$ plants $\left./ \mathrm{m}^{2}\right)$ and high $\mathrm{N}$ fertilization (100 kg N/ha) with (HI_sprayed) or without (HI) chemical protection against Phomopsis; (b) moderate crop density $\left(5.0 \mathrm{pl} / \mathrm{m}^{2}\right)$ and $\mathrm{N}$ rate $(80 \mathrm{~kg} \mathrm{~N} / \mathrm{ha}$ at head visible $)$, with (MI_sprayed) or without fungicide (MI); (c) management as for MI, but without N fertilization (MI_noN); (d) MI with a reduced crop density $\left(3.5 \mathrm{pl} / \mathrm{m}^{2}\right)$ : MI_low-d, and (e) combination of MI_noN and MI_low-d: low-input management (LI). In 1995, a similar experimental design was used to compare 4 systems: (a) high crop density $\left(7.5 \mathrm{pl} / \mathrm{m}^{2}\right)$ and high $\mathrm{N}$ rate $(100 \mathrm{~kg} \mathrm{~N} / \mathrm{ha})$, with (HI_sprayed) or without (HI) fungicide treatment, and (b) moderate crop density $\left(5.0 \mathrm{pl} / \mathrm{m}^{2}\right)$ and no $\mathrm{N}$ fertilization with (LI_sprayed) or without (LI) fungicide. 
Table III. Description of the main aspects of the crop management system experiments carried out at INRA and Cetiom from 1994 to 2000. HI: high-input, MI: medium-input, LI: low-input management systems, _irr: irrigated,_rfd: rainfed, _ls: late-sown.

\begin{tabular}{|c|c|c|c|c|c|c|c|c|c|}
\hline Experiment & Design & Year & Treatments & Cultivar(s) & $\begin{array}{c}\text { Sowing } \\
\text { date }\end{array}$ & $\begin{array}{c}\text { Plant } \\
\text { density } \\
\mathrm{pl} \cdot \mathrm{m}^{-2}\end{array}$ & $\begin{array}{c}\mathrm{N} \\
\text { fertilizer } \\
\mathrm{kg} \cdot \mathrm{ha}^{-1}\end{array}$ & $\begin{array}{l}\text { Irrigation } \\
\mathrm{mm} \cdot \mathrm{ha}^{-1}\end{array}$ & $\begin{array}{c}\text { Fungicide } \\
\text { (application date) }\end{array}$ \\
\hline INRA-94 & $\begin{array}{c}5 \text { systems } \\
\text { random distribution } \\
6-26 \text { replicates per } \\
\text { system }\end{array}$ & 1994 & $\begin{array}{l}\text { HI_irr } \\
\text { HI_rfd } \\
\text { MI_irr } \\
\text { MI_rfd } \\
\text { LI_rfd }\end{array}$ & $\begin{array}{l}\text { Select } \\
\text { Select } \\
\text { Select } \\
\text { Select } \\
\text { Select }\end{array}$ & $\begin{array}{l}2 \text { May } \\
2 \text { May } \\
2 \text { May } \\
2 \text { May } \\
2 \text { May }\end{array}$ & $\begin{array}{l}6.6 \\
6.9 \\
6.7 \\
6.9 \\
5.2\end{array}$ & $\begin{array}{l}80 \\
80 \\
60 \\
60 \\
30\end{array}$ & $\begin{array}{c}85 \\
0 \\
45 \\
0 \\
0\end{array}$ & $\begin{array}{c}21 \text { June }^{1} \\
21 \text { June }^{1} \\
\text { No } \\
\text { No } \\
\text { No }\end{array}$ \\
\hline Cetiom-94 & $\begin{array}{l}7 \text { systems } \\
\text { randomized } \\
4 \text { block s }\end{array}$ & 1994 & $\begin{array}{l}\text { HI } \\
\text { MI } \\
\text { MI_no-N } \\
\text { MI_low-d } \\
\text { LI }\end{array}$ & $\begin{array}{l}\text { Santiago, LG } 5410 \\
\text { Santiago, LG } 5410 \\
\text { Santiago, LG } 5410 \\
\text { Santiago, LG } 5410 \\
\text { Santiago, LG } 5410\end{array}$ & $\begin{array}{l}2 \text { May } \\
2 \text { May } \\
2 \text { May } \\
2 \text { May } \\
2 \text { May }\end{array}$ & $\begin{array}{l}6.1 \\
4.9 \\
4.9 \\
3.5 \\
3.5\end{array}$ & $\begin{array}{c}100 \\
80 \\
0 \\
80 \\
0\end{array}$ & $\begin{array}{l}0 \\
0 \\
0 \\
0 \\
0\end{array}$ & $\begin{array}{c}\text { No (HI), } 23 \text { June }^{2} \text { (HI_spr) } \\
\text { No (MI), } 23 \text { June }^{2} \text { (MI_spr) } \\
\text { No } \\
\text { No } \\
\text { No }\end{array}$ \\
\hline Cetiom-95 & $\begin{array}{l}4 \text { systems } \\
\text { randomized } \\
4 \text {-blocks }\end{array}$ & 1995 & $\begin{array}{l}\text { HI } \\
\text { LI }\end{array}$ & $\begin{array}{l}\text { Santiago } \\
\text { Santiago }\end{array}$ & $\begin{array}{l}6 \text { April } \\
6 \text { April }\end{array}$ & $\begin{array}{l}7.5 \\
5.0\end{array}$ & $\begin{array}{c}100 \\
0\end{array}$ & $\begin{array}{l}20 \\
20\end{array}$ & $\begin{array}{l}\text { No (HI), } 13 \text { June }^{1} \text { (HI_spr) } \\
\text { No (LI), } 13 \text { June }^{1} \text { (LI_spr) }\end{array}$ \\
\hline \multirow[t]{6}{*}{ ICS 95-00 } & $\begin{array}{c}2 \text { systems } \\
\text { large adjacent plots } \\
\text { unreplicated } \\
+ \\
\text { unsprayed areas } \\
\text { within HI plots }\end{array}$ & 1995 & $\begin{array}{l}\text { HI } \\
\text { LI }\end{array}$ & $\begin{array}{l}\text { Santiago } \\
\text { Asturia }\end{array}$ & $\begin{array}{l}2 \text { May } \\
2 \text { May }\end{array}$ & $\begin{array}{l}6.6 \\
5.0\end{array}$ & $\begin{array}{c}50 \\
0\end{array}$ & $\begin{array}{c}85 \\
0\end{array}$ & $\begin{array}{c}\text { No (HI), } 27 \text { June }^{1} \text { (HI_spr) } \\
\text { No }\end{array}$ \\
\hline & & 1996 & $\begin{array}{c}\text { HI } \\
\text { LI_ls }\end{array}$ & $\begin{array}{l}\text { Santiago } \\
\text { Albena }\end{array}$ & $\begin{array}{l}10 \text { April } \\
15 \text { May }\end{array}$ & $\begin{array}{l}6.1 \\
6.1\end{array}$ & $\begin{array}{c}110 \\
40\end{array}$ & $\begin{array}{c}135 \\
0\end{array}$ & $\begin{array}{c}\text { No (HI), } 17 \text { June }^{1} \text { (HI_spr) } \\
\text { No }\end{array}$ \\
\hline & & 1997 & $\begin{array}{l}\text { HI } \\
\text { LI }\end{array}$ & $\begin{array}{l}\text { Melody } \\
\text { Labrador }\end{array}$ & $\begin{array}{l}9 \text { April } \\
9 \text { April }\end{array}$ & $\begin{array}{l}6.1 \\
6.1\end{array}$ & $\begin{array}{c}120 \\
65\end{array}$ & $\begin{array}{c}100 \\
0\end{array}$ & $\begin{array}{c}\text { No (HI), } 17 \text { June }^{1} \text { (HI_spr) } \\
\text { No }\end{array}$ \\
\hline & & 1998 & $\begin{array}{l}\text { HI } \\
\text { LI }\end{array}$ & $\begin{array}{l}\text { Melody } \\
\text { Labrador }\end{array}$ & $\begin{array}{l}10 \text { April } \\
10 \text { April }\end{array}$ & $\begin{array}{l}6.9 \\
5.6\end{array}$ & $\begin{array}{c}120 \\
60\end{array}$ & $\begin{array}{c}130 \\
0\end{array}$ & $\begin{array}{c}\text { No (HI), } 9 \text { June }^{1} \text { (HI_spr) } \\
\text { No }\end{array}$ \\
\hline & & 1999 & $\begin{array}{l}\text { HI } \\
\text { LI }\end{array}$ & $\begin{array}{l}\text { Melody } \\
\text { Labrador }\end{array}$ & $\begin{array}{l}8 \text { April } \\
8 \text { April }\end{array}$ & $\begin{array}{l}6.9 \\
6.9\end{array}$ & $\begin{array}{c}125 \\
70\end{array}$ & $\begin{array}{c}120 \\
0\end{array}$ & $\begin{array}{c}\text { No (HI), } 4 \text { June }^{1} \text { (HI_spr) } \\
\text { No }\end{array}$ \\
\hline & & 2000 & $\begin{array}{c}\text { HI } \\
\text { LI } \\
\text { LI_ls }\end{array}$ & $\begin{array}{l}\text { Melody } \\
\text { Albena } \\
\text { Albena }\end{array}$ & $\begin{array}{l}22 \text { April } \\
22 \text { April } \\
3 \text { May }\end{array}$ & $\begin{array}{l}6.2 \\
4.7 \\
5.0\end{array}$ & $\begin{array}{c}120 \\
65 \\
20\end{array}$ & $\begin{array}{c}80 \\
0 \\
0\end{array}$ & $\begin{array}{c}\text { No (HI), } 16 \text { June }^{1} \text { (HI_spr) } \\
\text { No } \\
\text { No }\end{array}$ \\
\hline
\end{tabular}

${ }^{1}$ Punch CS (carbendazim + flusilazole) $0.81 \cdot \mathrm{ha}^{-1}$.

${ }^{2}$ Corvet Flo (fenpropimorph + mancozeb + carbendazim) $2.51 \cdot \mathrm{ha}^{-1}$.

ICS 95-00 (INRA). The application of predefined decision rules for sunflower management was evaluated on a design composed of plots with an agricultural size (1.5 ha) which was set up in 1995 for the study of Integrated Cropping Systems [8]. Under high-input management (HI), a high yield target of $3500 \mathrm{~kg} / \mathrm{ha}$ involved early sowing, high plant density, high $\mathrm{N}$ rate, irrigation around anthesis, and fungicide protection (against Phomopsis), justified by the choice of a productive but moderately susceptible genotype and by higher risks of infection in such a system. Three replicates of $100 \mathrm{~m}^{2}$ were kept free of fungicides within each of the HI plots in order to check the effectiveness of chemical control (HI_unsprayed). In a low-input rainfed system (LI) designed for vegetative rationing through reduced plant density and moderate $\mathrm{N}$ fertilization at sowing, target yield was set at $2500 \mathrm{~kg} / \mathrm{ha}$. Crop rationing was applied in order to reduce the use of fungicides and a phomopsis-tolerant cultivar was chosen. Sowing was delayed in the LI system in 1996 and 2000 because of high precipitation in April. The operational decisions resulting from these rules are given in Table III.

\subsection{Observations and measurements}

The fraction of photosynthetically active radiation intercepted by the sunflower canopy (fPARi) was measured regularly from the star bud to early anthesis stages using the hand-held Picqhelios apparatus (AERIC, Balma) [34]. This synthetic variable has a strong relation to leaf area index and to the level of intensity of sunflower management (nitrogen, plant density and pre-anthesis irrigation) $[5,10]$. The frequency of measurement differed with the experiments but the value of fPARi was determined at early anthesis in each experiment. While walking a distance of 5-15 meters (or for less than 20 seconds) between adjacent plant rows, $f$ PARi was measured 
Table IV. Monthly precipitation (mm) and number of days where $T_{\max }>32{ }^{\circ} \mathrm{C}$ (Auzeville station).

\begin{tabular}{ccccccccc}
\hline \multicolumn{4}{c}{ Precipitation (mm) } & \multicolumn{4}{c}{$\begin{array}{c}\text { Number of days } \\
\text { where } T_{\max }>32{ }^{\circ} \mathrm{C}\end{array}$} \\
\hline & April & May & June & July & August & June & July & August \\
1994 & 123 & 34 & 75 & 11 & 3 & 2 & 7 & 8 \\
1995 & 38 & 78 & 53 & 67 & 20 & 1 & 7 & 3 \\
1996 & 64 & 108 & 25 & 71 & 78 & 2 & 6 & 1 \\
1997 & 29 & 87 & 65 & 28 & 126 & 0 & 0 & 7 \\
1998 & 111 & 67 & 17 & 56 & 16 & 1 & 7 & 8 \\
1999 & 77 & 110 & 24 & 56 & 45 & 0 & 7 & 3 \\
2000 & 80 & 48 & 131 & 39 & 37 & 0 & 3 & 8 \\
\hline
\end{tabular}

continuously by the sensor then a time-integrated average was calculated. The measurement was repeated twice or four times in different inter-rows to represent the canopy variability.

Phomopsis symptoms on stems were scored on 20 to 50 plants from 10 to 20 August using a scale proposed by Pinochet [35]: 1. healthy plant; 2 . plants with shallow spots on the stem; 3. plants with girdling spots on the stem, and 4 . wilted or broken stems. Only symptoms in classes 3 and 4 were considered to be detrimental to yield.

At harvest, dry achene yield was determined after oven-drying achene samples at $80{ }^{\circ} \mathrm{C}$ for $48 \mathrm{~h}$. Achene yield was determined in crop management systems and in Cetiom experiments.

Economic returns were assessed by calculating the gross margin (Euros/ha) for the experiments, where yield was measured according to:

$\mathrm{GM}=($ Commercial yield $\times$ Price $)-$ Cost of inputs (seeds, nitrogen, water and fungicides).

A relative gross margin was calculated using the high-input management as the reference (100).

\subsection{Statistical procedure}

The data were analyzed statistically using the Statistix 7.0 program (Analytical Software, Tallahassee, FL, USA). Means were compared by the LSD (least significant difference) method at the $P<0.05$ level of significance.

\section{RESULTS}

\subsection{Weather conditions and stem canker development}

The Plant Protection Service of the Ministry of Agriculture has developed a predictive model of disease spread (Asphodel) which is now used in practice to improve farmers' spraying decisions $[15,16]$. The model was run for Auzeville to represent the epidemic process (asci maturation, spore release and leaf infection) in each growing season. The weather and epidemic conditions were assumed to be comparable between the 2 locations. The monthly weather records for Auzeville from 1994 to 2000 are shown in Table IV.
Table V. Simulation of spore release and infection events with the Asphodel model (Auzeville station).

\begin{tabular}{lcc}
\hline & $\begin{array}{c}\text { Beginning of spore release } \\
(50 \% \text { matured asci) }\end{array}$ & $\begin{array}{c}\text { Number of infection events during } \\
\text { the most susceptible period } \\
\text { (star bud to anthesis) }\end{array}$ \\
\hline 1994 & 17 May & 4 \\
1995 & 26 May & 3 \\
1996 & 7 May & 2 \\
1997 & 15 May & 2 \\
1998 & 15 May & 1 \\
1999 & 4 May & 0 \\
2000 & 17 May & 4 \\
\hline
\end{tabular}

According to Asphodel, a minimum of $50 \%$ of asci must have matured before significant spore release and leaf infection events are expected. This threshold was generally reached around 15 May but early spore release was possible as early as 4 May in 1999 and not before 26 May in 1995 because of dry, cool spring conditions (Tab. V). Up to 4 significant events of leaf infection were simulated in 1994 and 2000 during the period where the sunflower crop was the most vulnerable to Phomopsis attack. Lack of rain in June resulted in a small number of infection events in 1998 and 1999 while 2-3 events were observed in 1995 (late spore release), in 1996 (only for early-sown crops) and in 1997. Infections after anthesis did not result in many symptoms on stems as a result of their late establishment on the leaves and high summer temperatures.

Frequent or abundant rainfall from budding (first part of June) to the flowering stage appears to be more important for successful infection than temperature, but temperatures exceeding $32{ }^{\circ} \mathrm{C}$ after leaf infection can stop growth or even kill the mycelium in its progression towards the stem [22]. Except in 1997 and 2000 where both humidity and temperature were favorable to the spread of symptoms (Tab. IV), conditions for massive stem colonization were not encountered because of summer drought and high temperatures in July and August.

The use of semi-natural infection techniques (introduction of infected stalks and split irrigation), especially in 1996 and 1999, was a way of compensating for the lack of rain and reduced spore release. The importance of the primary inoculum was demonstrated in 2000 by the comparison of plots I (semi-natural infection) and $\mathrm{H}$ (natural infection), which did not differ except by the presence of fragments of infected stalks in the crop interrow in I: $75 \%$ of the stems were infected in I versus $42 \%$ in $\mathrm{H}$. For each combination of cultivar, crop density, $\mathrm{N}$ amount and irrigation supply, the proportion of infected stems in I was compared with the corresponding situation in $\mathrm{H}$ (80 pairs) (Fig. 1). The level of attack in I was much higher than in $\mathrm{H}$, with infection levels reaching $100 \%$ in I while in similar plots with natural infection only $30 \%$ infection was found. The proportion of girdling lesions did not reach the $100 \%$ level and differed between management treatments even under conditions of high infection pressure. 


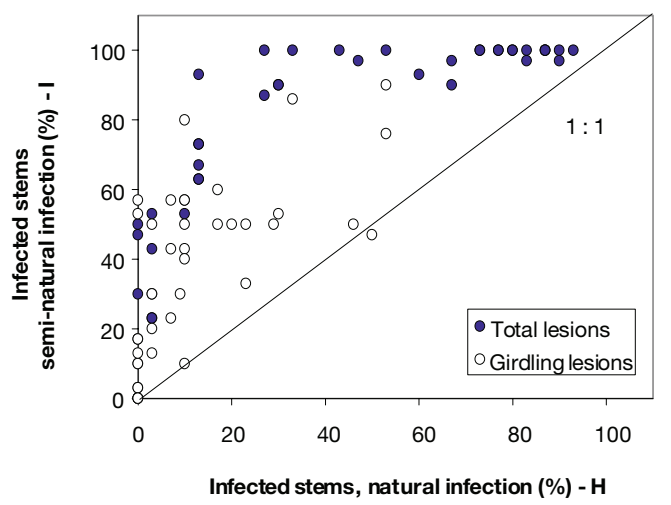

Figure 1. Effect of spreading infected fragments of sunflower between the rows (semi-natural infection) on the proportion of stems infected by Phomopsis (closed circles: total lesions; open circles: girdling lesions): experiment INRA-00 (I vs. H).

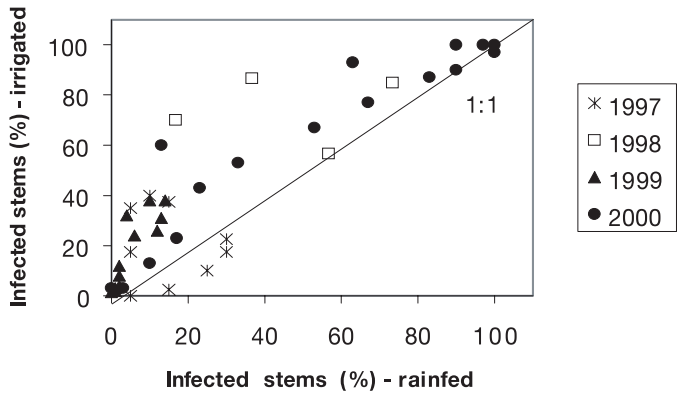

Figure 2. Effect of irrigation on percentage infected stems in different growing seasons in four experiments (stars: INRA-97, open squares: INRA-98, black triangles: INRA-99, black circles: INRA$00)$.

\subsection{Individual effects of irrigation, plant density, $\mathbf{N}$ fertilization and cultivar on the proportion of stems infected by Diaporthe helianthi}

In this section, we analyze the proportion of infected stems in pairs of treatments differing in only one agronomic factor (irrigation, crop density, $\mathrm{N}$ amount or cultivar, respectively) based on the 9 factorial trials (Tab. II).

\subsubsection{Irrigation}

During the period 1997-2000, irrigation applied around flowering resulted in a clear increase in infected stems $(+22 \%$ on average) in almost all the 41 situations (Fig. 2).

\subsubsection{Crop density}

The effect of increasing crop density on the proportion of sunflower stems with at least one canker lesion was evaluated by comparing 60 pairs of experimental plots differing only by the density factor (Fig. 3). The plant densities ranged from 3.5 (d1) to 9 plants $/ \mathrm{m}^{2}$ (d5). The density difference between

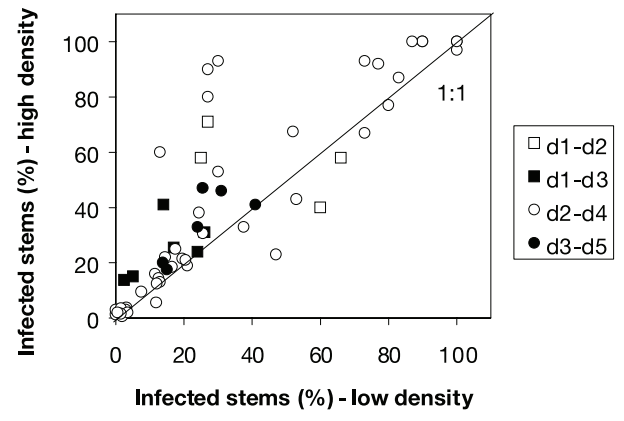

Figure 3. Effect of crop density $\left(\mathrm{d} 1: 3.5 \mathrm{pl} \cdot \mathrm{m}^{-2} ; \mathrm{d} 2: 5.0 \mathrm{pl} \cdot \mathrm{m}^{-2}\right.$; $\mathrm{d} 3$ : $6.5 \mathrm{pl} \cdot \mathrm{m}^{-2} ; \mathrm{d} 4: 7.5 \mathrm{pl} \cdot \mathrm{m}^{-2} ; \mathrm{d} 5: 9 \mathrm{pl} \cdot \mathrm{m}^{-2}$ ) on total infected stems: experiments INRA-97, INRA-98, INRA-99, INRA-00H, INRA-00I, Cetiom-94, Cetiom-99S, Cetiom-99I, Cetiom-00. Open squares: d1 compared with d2, closed squares: d1 vs. d3, open circles: d2 vs. d4, closed circles: d3 vs. d5).

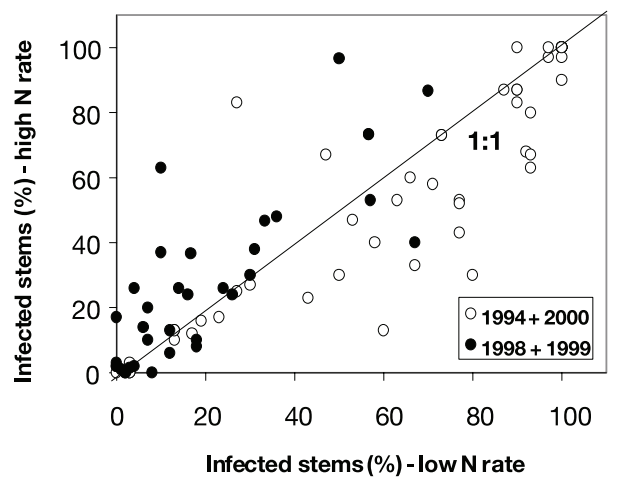

Figure 4. Effect of $\mathrm{N}$-fertilizer rate on total infected stems under conditions of high infection (open circles: Cetiom-94, Cetiom-00, INRA-00H, INRA-00I) or low infection (closed circles: INRA-98, INRA-99, Cetiom-99S, Cetiom-99I).

two comparisons ranged from 1.5 to 3 plants $/ \mathrm{m}^{2}$. In $70 \%$ of the pairs that were compared, the proportion of infected stems was higher after increasing crop density. In only a few situations, more stems were infected in sparser stands. When increasing plant density from $5.0(\mathrm{~d} 2)$ to 7.5 plants $/ \mathrm{m}^{2}$ (d4), the infection percentage had an increase of $22 \%$ on average (44 pairs) but the increase was higher when considering only girdling lesions $(82 \%)$. In conditions of moderate infection at low density (i.e. $20-40 \%$ infected stems), increasing crop density resulted in a strong response in infected stems.

\subsubsection{Nitrogen amount}

Increasing $\mathrm{N}$ supply in 83 pairs of plots resulted in opposite effects on the proportion of infected stems (Fig. 4). At low infection levels (1998 and 1999), the proportion of stems with lesions increased in most of the situations when 60 to $120 \mathrm{~kg}$ $\mathrm{N} / \mathrm{ha}$ were supplied. In this case, the average increase in infection percentage was $36 \%$. Surprisingly, more stems (+14\%) 


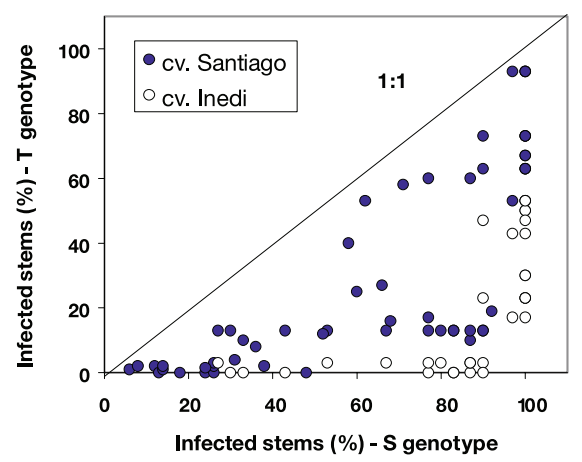

Figure 5. Effect of cultivar susceptibility to Phomopsis (S: Susceptible; $\mathrm{T}$ : Tolerant) on the proportion of infected stems for a range of infection conditions (closed circles: cv. Santiago as the tolerant genotype, open circles: cv. Inedi as the tolerant genotype).

were infected by Phomopsis on plots receiving no nitrogen at sowing when infection pressure was high, due to infected stalk spreading in combination with a rainy spring, as in 1994 and 2000.

\subsubsection{Cultivar}

The proportion of infected stems was compared between susceptible (cv. Olbaril, cv. DK 3790 and cv. Proleic 204) and tolerant (cv. Santiago and cv. Inedi) cultivars. As was expected, in each of the 89 comparisons, more symptoms were observed on the susceptible cultivar (Fig. 5). Although cv. Inedi and cv. Santiago were both considered to be tolerant, the former maintained lower attack levels on a wider range of inoculum pressure (indicated here by the proportion of infected stems on the susceptible cultivar). The difference in infected stems between susceptible and tolerant cultivars was reduced for $\mathrm{cv}$. Inedi under conditions of high infection ( $>90 \%$ of S cultivar stems infected by Phomopsis).

\subsection{Effect of the fraction of PAR intercepted by the sunflower crop on the proportion of stems infected by Diaporthe helianthi}

The proportion of infected stems increased exponentially (from 0 to $100 \%$ ) with the fraction of PAR intercepted (55$95 \%$ ) in all the unsprayed experiments, when keeping only the 129 plots (from 1994 to 2000) where natural conditions did not restrict Phomopsis development (early sowing, rainy seasons and irrigation) (Fig. 6). Treatments resulting in massive leaf and stem colonization (inoculation) or disrupting the infection process (late sowing, drought and fungicides) were not plotted in Figure 6. In such conditions, for cultivars ranging from the $\mathrm{S}$ to $\mathrm{T}$ susceptibility classes, the effect of the canopy accounted for $67 \%$ of the variation of stem attack. When fPARi exceeded $85 \%$ (i.e. $\mathrm{LAI}>2.5$ ), the proportion of infected stems increased rapidly. Below this threshold, the infection percentage was less than 20\%. Stimulating the leaf area index (by increasing crop density and $\mathrm{N}$ fertilization) resulted in an increase in the proportion of infected stems irrespective of the genotypic tolerance.

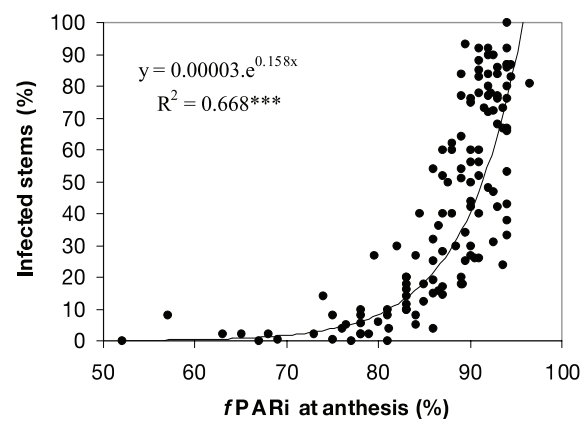

Figure 6. Relation between the proportion of stems infected by Phomopsis and the fraction of PAR intercepted by the sunflower crop at anthesis for weather conditions promoting leaf and stem infection $(\mathrm{n}=129)-\mathrm{S}, \mathrm{MS}$ and T genotypes were confounded.

\subsection{Control of Phomopsis by crop management systems}

\subsubsection{INRA-94 experiment}

The highest infection levels were observed with irrigation (HI_irr and MI_irr) and in the situations where the leaf area index was high enough to facilitate a successful infection by ascospores (MI_rfd, unsprayed) (Tab. VI). Irrigation around anthesis allowed the summer development of leaf symptoms in conditions of water deficit and high temperature, which were responsible for rapid senescence in 1994.

The proportion of stems infected was significantly reduced in the LI_rfd treatment where severe crop rationing was applied by reducing plant density by $25 \%$ and $\mathrm{N}$ fertilization by $60 \%$. In the absence of fungicide, this resulted in a higher yield than in the MI_rfd treatment. For a similar level of symptoms but increased potential yields (HI_rfd), the use of a fungicide was essential. Comparing $\mathrm{HI}$ and $\mathrm{MI}$ with irrigation and in rainfed conditions, the use of fungicide was responsible for a yield gain of 460 and $430 \mathrm{~kg} / \mathrm{ha}$, respectively. The percentage of broken stems (the ultimate effect of Phomopsis) increased from LI_rfd (0.5\%) to HI_irr (7\%) together with leaf area index, crop height and head yield (data not shown).

\subsubsection{Cetiom experiments (1994-1996)}

1994. Rationing sunflower by reducing plant density (MI_low-d vs. MI), nitrogen fertilization (MI_noN vs. MI) or both (comparison of HI, MI and LI) resulted in a lower leaf area index at anthesis and a lower proportion of stems bearing lesions of Phomopsis (Tab. VI). Although the average level of infection differed between the susceptible (11\% of stems with girdling lesions without fungicide for LG5410) and the tolerant genotype (5\% for Santiago), there was no significant interaction of crop management with genotype tolerance. The proportion of stems with yield-reducing symptoms was moderate, amounting to $15 \%$ in the highest-risk situation (susceptible genotype, high-input management and no chemical protection).

The LI strategy was the most effective in reducing the occurrence of Phomopsis without fungicide, while for $\mathrm{HI}$ and 
Table VI. Effect of crop management system on the proportion of stems infected by Phomopsis and on sunflower production (HI: high-input, MI: medium input, LI: low-input system, ES: early-sown, LS: late-sown ,_irr: irrigated,_rfd: rainfed,_spr: fungicide applied).

\begin{tabular}{|c|c|c|c|c|c|c|c|c|c|}
\hline Exp. & Year & Treatments & Cultivar & Fungicide & $\begin{array}{c}\text { fPARi at } \\
\text { anthesis } \\
(\%)\end{array}$ & $\begin{array}{l}\text { Total lesions } \\
\text { (\% stems) }\end{array}$ & $\begin{array}{c}\text { Girdling } \\
\text { lesions } \\
\text { (\% stems })\end{array}$ & $\begin{array}{c}\text { Achene } \\
\text { dry yield }\left(\mathrm{kg} \cdot \mathrm{ha}^{-1}\right)\end{array}$ & $\begin{array}{c}\text { Relative gross } \\
\text { margin }\end{array}$ \\
\hline \multirow[t]{5}{*}{ INRA-94 } & 1994 & HI_irr & Select & Yes & $93 \mathrm{a}$ & $61 \mathrm{a}$ & $23 \mathrm{ab}$ & $2960 \mathrm{a}$ & 100 \\
\hline & & HI_rfd & $(\mathrm{T})$ & Yes & $90 \mathrm{a}$ & $33 \mathrm{~b}$ & $12 \mathrm{bc}$ & $2560 \mathrm{~b}$ & 95 \\
\hline & & MI_irr & & No & $90 \mathrm{a}$ & $59 a$ & $28 \mathrm{a}$ & $2500 \mathrm{bc}$ & 92 \\
\hline & & MI_rfd & & No & $89 \mathrm{a}$ & $51 \mathrm{a}$ & $21 \mathrm{ab}$ & $2130 \mathrm{~d}$ & 81 \\
\hline & & LI_rfd & & No & $84 \mathrm{~b}$ & $32 \mathrm{~b}$ & $9 \mathrm{c}$ & $2280 \mathrm{~cd}$ & 97 \\
\hline \multirow[t]{14}{*}{ Cetiom-94 } & 1994 & HI & Santiago & No & $88.5 \mathrm{a}$ & $53 \mathrm{~b}$ & $9.5 \mathrm{a}$ & $3020 \mathrm{~b}$ & 92 \\
\hline & & HI_spr & $(\mathrm{T})$ & Yes & $87.5 \mathrm{ab}$ & $2 \mathrm{~d}$ & $0 \mathrm{~b}$ & $3360 \mathrm{a}$ & 100 \\
\hline & & MI & & No & $84.5 \mathrm{bc}$ & $58 \mathrm{~b}$ & $9 \mathrm{a}$ & $3030 \mathrm{~b}$ & 97 \\
\hline & & MI_spr & & Yes & $85.5 \mathrm{abc}$ & $5 \mathrm{~d}$ & $0 \mathrm{~b}$ & $3560 \mathrm{a}$ & 112 \\
\hline & & MI_no-N & & No & $76.5 \mathrm{~d}$ & $71 \mathrm{a}$ & $1.5 \mathrm{~b}$ & $2960 \mathrm{~b}$ & 97 \\
\hline & & MI_low-d & & No & $83 \mathrm{c}$ & $25 \mathrm{c}$ & $5 a b$ & $3060 \mathrm{~b}$ & 102 \\
\hline & & LI & & No & $74 \mathrm{~d}$ & $27 \mathrm{c}$ & $0.5 \mathrm{~b}$ & $2880 \mathrm{~b}$ & 98 \\
\hline & & HI & LG 5410 & No & $87 \mathrm{a}$ & $62 \mathrm{a}$ & $14.5 \mathrm{a}$ & $2440 \mathrm{c}$ & 88 \\
\hline & & HI_spr & (S) & Yes & $87 \mathrm{a}$ & $12 \mathrm{c}$ & $0 \mathrm{c}$ & $2820 \mathrm{ab}$ & 100 \\
\hline & & MI & & No & $85 a b$ & $40 \mathrm{~b}$ & $12.5 \mathrm{a}$ & $2550 \mathrm{abc}$ & 99 \\
\hline & & MI_spr & & Yes & $85.5 \mathrm{ab}$ & $13 \mathrm{c}$ & $2 c$ & $2840 \mathrm{a}$ & 106 \\
\hline & & MI_no-N & & No & $83 \mathrm{~b}$ & $58 \mathrm{ab}$ & $10 \mathrm{ab}$ & $2330 \mathrm{~cd}$ & 92 \\
\hline & & MI_low-d & & No & $83 \mathrm{~b}$ & $60 a b$ & $11.5 \mathrm{ab}$ & $2520 \mathrm{bc}$ & 102 \\
\hline & & LI & & No & $78 \mathrm{c}$ & $66 \mathrm{a}$ & $5.5 \mathrm{bc}$ & $2130 \mathrm{~d}$ & 88 \\
\hline \multirow[t]{4}{*}{ Cetiom-95 } & 1995 & HI & Santiago & No & $96.5 \mathrm{a}$ & $38 \mathrm{a}$ & 24 & $3600 \mathrm{~b}$ & 93 \\
\hline & & HI_spr & $(\mathrm{T})$ & Yes & $96.5 \mathrm{a}$ & $9 \mathrm{~b}$ & 8 & 3940 a & 100 \\
\hline & & LI & & No & $93 \mathrm{~b}$ & $32 \mathrm{a}$ & 16 & $3660 \mathrm{~b}$ & 105 \\
\hline & & LI_spr & & Yes & $93.5 \mathrm{~b}$ & $4 \mathrm{~b}$ & 2 & $3890 \mathrm{a}$ & 108 \\
\hline \multirow[t]{4}{*}{ Cetiom-96 } & 1996 & ES & LG 5830 & No & $92 \mathrm{~b}$ & $48 \mathrm{a}$ & $10 \mathrm{a}$ & $3360 \mathrm{~b}$ & 91 \\
\hline & & ES_spr & (T) & Yes & $92.5 \mathrm{ab}$ & $6 \mathrm{~b}$ & $1 \mathrm{~b}$ & $3730 a$ & 100 \\
\hline & & LS & & No & $93.5 \mathrm{ab}$ & $4 \mathrm{bc}$ & $0 \mathrm{~b}$ & $3600 \mathrm{a}$ & 100 \\
\hline & & LS_spr & & Yes & $94.5 \mathrm{a}$ & $0 \mathrm{c}$ & $0 \mathrm{~b}$ & $3650 \mathrm{a}$ & 97 \\
\hline
\end{tabular}

For a given experiment, within each column, values followed by the same letter are not significantly different at $P<0.05$. The absence of letters indicates non significant effects.

MI strategies without chemical protection results were not consistent. Yield increase with fungicide ranged from 290 to $530 \mathrm{~kg} / \mathrm{ha}$ depending on the cultivar and input level (HI or $\mathrm{MI})$, which economically justified the use of a fungicide in such conditions.

1995. The average level of girdling lesions on cv. Santiago was higher than in 1994 as a result of an early sowing date and higher leaf area index from star bud to anthesis, which allowed early infections to succeed and cause severe lesions (Tab. VI). In such conditions, the level of infection was not significantly different between HI and LI, in spite of the range of plant density and $\mathrm{N}$ amount. The response of yield to the application of fungicide was $+340 \mathrm{~kg} / \mathrm{ha}(\mathrm{HI})$ and $+230 \mathrm{~kg} / \mathrm{ha}(\mathrm{LI})$ for cv. Santiago, in agreement with the proportion of stems with yield-reducing symptoms (24\% for HI, $16 \%$ for LI).

1996. Delaying sowing decreased the occurrence and severity of the Phomopsis attacks (Tab. VII). In such conditions, the use of a fungicide was not profitable (SprayedUnsprayed $=+50 \mathrm{~kg} / \mathrm{ha}$ ). On the other hand, spraying was justified with early sowing $(+370 \mathrm{~kg} / \mathrm{ha})$ because of the severity of girdling lesions $(10 \%)$ but also because of the control of Phoma by Corvet Flo. At anthesis, leaf area index was slightly greater on late-sown sunflower: the positive effect of delaying sowing from 1 to 30 April was due to a shifting of the sunflower bud stages towards periods less favorable to infection (escaping strategy) and not to a limitation by canopy growth and microclimate (rationing strategy).

1999. With natural infection, without irrigation (Cetiom99S), the fraction of girdling lesions did not exceed $8 \%$ for the susceptible cv. Olbaril, which is less than the economic threshold for fungicide application. Combining high crop density and high $\mathrm{N}$ supply was favorable to the development of Phomopsis due to the high leaf area index (Tab. VII). Cv. Santiago, which is tolerant and did not attain a high leaf area index, was only slightly infected by Phomopsis. When fragments of stalks were scattered in the inter-rows and combined with irrigation, the economic threshold was exceeded for cv. Olbaril, whatever the management options. The attacks were still moderate on cv. Santiago.

As in the rainfed treatment, increasing density and nitrogen under irrigation was favorable to the development of Phomopsis, and without fungicide the yield of cv. Olbaril was the lowest in such conditions of high inputs. For cv. Santiago (a shortstatured genotype), increasing $\mathrm{N}$ and plant density was the way to improve grain production even without fungicide protection, while for cv. Olbaril, the rationed management (low $\mathrm{N}$ 
Table VII. Effect of cultivar (cv. Olbaril, susceptible, cv. Santiago, tolerant), crop density $\left(\mathrm{d} 1=5\right.$ plants $\left.\cdot \mathrm{m}^{-2}, \mathrm{~d} 2=8 \mathrm{plants} \cdot \mathrm{m}^{-2}\right)$ and $\mathrm{N}$ fertilization $\left(0 \mathrm{~N}=\right.$ no fertilization; $\left.120 \mathrm{~N}: 120 \mathrm{~kg} \mathrm{~N} \cdot \mathrm{ha}^{-1}\right)$ on the proportion of stems infected by Phomopsis and on sunflower production in unsprayed conditions.

\begin{tabular}{|c|c|c|c|c|c|c|c|c|}
\hline Exp. & Year & Treatments & Cultivar & $\begin{array}{c}\text { fPARi at anthesis } \\
(\%)\end{array}$ & $\begin{array}{l}\text { Total lesions } \\
\text { (\% stems })\end{array}$ & $\begin{array}{l}\text { Girdling lesions } \\
\text { (\% stems) }\end{array}$ & $\begin{array}{c}\text { Achene } \\
\text { dry yield }\left(\mathrm{kg} \cdot \mathrm{ha}^{-1}\right)\end{array}$ & $\begin{array}{c}\text { Relative gross } \\
\text { margin }\end{array}$ \\
\hline \multirow{2}{*}{ Cetiom-99S } & \multirow{8}{*}{1999} & $\mathrm{~d} 1 \_120 \mathrm{~N}$ & Olbaril (S) & $92 \mathrm{a}$ & $12.5 \mathrm{a}$ & 5.6 & $3810 \mathrm{a}$ & 110 \\
\hline & & d1_0N & & $87 \mathrm{~b}$ & $11.9 \mathrm{a}$ & 5.0 & $3230 \mathrm{~b}$ & 95 \\
\hline \multirow{6}{*}{$\begin{array}{l}\text { not irrigated } \\
\text { not inoculated }\end{array}$} & & $\mathrm{d} 2 \_120 \mathrm{~N}$ & & $93 \mathrm{a}$ & $14.4 \mathrm{a}$ & 8.1 & $3700 \mathrm{a}$ & 100 \\
\hline & & d2_0N & & $87.5 \mathrm{~b}$ & $5.6 \mathrm{~b}$ & 4.4 & $3130 \mathrm{~b}$ & 85 \\
\hline & & d1_120N & Santiago $(\mathrm{T})$ & $91 \mathrm{a}$ & 0 & 0 & 3770 a & 85 \\
\hline & & $\mathrm{d} 1 \_0 \mathrm{~N}$ & & $85 \mathrm{~b}$ & 1.9 & 0 & $3390 \mathrm{ab}$ & 91 \\
\hline & & $\mathrm{d} 2 \_120 \mathrm{~N}$ & & $91 \mathrm{a}$ & 1.3 & 0 & 3980 a & 100 \\
\hline & & $\mathrm{d} 2 \_0 \mathrm{~N}$ & & $83 \mathrm{~b}$ & 0.6 & 0.6 & $3060 \mathrm{~b}$ & 76 \\
\hline \multirow[t]{2}{*}{ Cetiom-99I } & \multirow[t]{8}{*}{1999} & $\mathrm{~d} 1 \_120 \mathrm{~N}$ & Olbaril (S) & $93.5 \mathrm{ab}$ & $24.4 \mathrm{~b}$ & $13.7 \mathrm{~b}$ & $2890 \mathrm{ab}$ & 149 \\
\hline & & d1 $10 \mathrm{~N}$ & & $90.5 \mathrm{~b}$ & $25.6 \mathrm{~b}$ & $18.1 \mathrm{ab}$ & $3360 \mathrm{a}$ & 195 \\
\hline irrigated & & d2__120N & & $94 \mathrm{a}$ & $38.1 \mathrm{a}$ & $26.3 \mathrm{a}$ & $2450 \mathrm{~b}$ & 100 \\
\hline \multirow[t]{5}{*}{ inoculated } & & $\mathrm{d} 2 \_0 \mathrm{~N}$ & & $92.5 \mathrm{ab}$ & $30.6 \mathrm{~b}$ & $18.7 \mathrm{ab}$ & $2600 \mathrm{~b}$ & 121 \\
\hline & & d1__120N & Santiago $(T)$ & $89.5 \mathrm{a}$ & $1.3 \mathrm{~b}$ & $0 \mathrm{c}$ & $3640 a b$ & 101 \\
\hline & & $\mathrm{d} 1 \_0 \mathrm{~N}$ & & $85 \mathrm{~b}$ & $3.1 \mathrm{ab}$ & $1.9 \mathrm{ab}$ & $3190 \mathrm{c}$ & 89 \\
\hline & & $\mathrm{d} 2 \_120 \mathrm{~N}$ & & $90 \mathrm{a}$ & $1.9 \mathrm{ab}$ & $0.6 \mathrm{bc}$ & $3790 \mathrm{a}$ & 100 \\
\hline & & $\mathrm{d} 2 \_0 \mathrm{~N}$ & & $85.5 \mathrm{~b}$ & $3.8 \mathrm{a}$ & $3.1 \mathrm{a}$ & $3360 \mathrm{bc}$ & 88 \\
\hline \multirow[t]{2}{*}{ Cetiom-00 } & \multirow[t]{8}{*}{2000} & $\mathrm{~d} 1 \_120 \mathrm{~N}$ & Olbaril (S) & 91 & $52 \mathrm{~b}$ & $16.5 \mathrm{c}$ & $2360 \mathrm{a}$ & 152 \\
\hline & & $\mathrm{d} 1 \_0 \mathrm{~N}$ & & 92 & $77 \mathrm{ab}$ & $52.5 \mathrm{ab}$ & $2120 \mathrm{a}$ & 142 \\
\hline irrigated & & $\mathrm{d} 2 \_120 \mathrm{~N}$ & & 92.5 & $67.5 \mathrm{ab}$ & $41 \mathrm{bc}$ & $1970 \mathrm{ab}$ & 100 \\
\hline \multirow[t]{5}{*}{ inoculated } & & $\mathrm{d} 2 \_0 \mathrm{~N}$ & & 91 & $92 \mathrm{a}$ & $75 \mathrm{a}$ & $1600 \mathrm{~b}$ & 79 \\
\hline & & $\mathrm{d} 1 \_120 \mathrm{~N}$ & Santiago $(\mathrm{T})$ & $90 \mathrm{a}$ & $11.5 \mathrm{~b}$ & 2.5 & $3290 \mathrm{a}$ & 119 \\
\hline & & $\mathrm{d} 1 \_0 \mathrm{~N}$ & & $87 \mathrm{~b}$ & $16.5 \mathrm{a}$ & 6 & $2940 \mathrm{~b}$ & 109 \\
\hline & & $\mathrm{d} 2 \_120 \mathrm{~N}$ & & $90 \mathrm{a}$ & $16 \mathrm{ab}$ & 7 & $3060 \mathrm{ab}$ & 100 \\
\hline & & $\mathrm{d} 2 \_0 \mathrm{~N}$ & & $86 \mathrm{~b}$ & $18.5 \mathrm{a}$ & 6.5 & $2960 \mathrm{~b}$ & 101 \\
\hline
\end{tabular}

For a given experiment, within each cultivar, values followed by the same letter are not significantly different at $P<0.05$. The absence of letters indicates non significant effects.

and low density) resulted in the highest yield. Without irrigation, when the occurrence of Phomopsis was limited, the management options using more $\mathrm{N}$ resulted in higher yields irrespective of the disease susceptibility of the cultivar.

2000. Under weather conditions favorable to the expression of symptoms, the proportion of stems bearing Phomopsis lesions was extremely high for cv. Olbaril (52 to $92 \%$ depending on the management option) (Tab. VI).

Although cv. Santiago was attacked more severely than in 1999, the economic threshold for spraying was not reached for this tolerant genotype. Yield losses were higher than in 1999: $430 \mathrm{~kg} / \mathrm{ha}$ for cv. Santiago and $790 \mathrm{~kg} / \mathrm{ha}$ for cv. Olbaril. Without fungicide, reducing crop density was a sound way of limiting yield loss in susceptible genotypes such as cv. Olbaril.

\subsubsection{The ICS experiment (1995-2000) - Tab. VIII}

The reduction in crop density and nitrogen rate in management system LI generally resulted in a smaller fraction of PAR intercepted at anthesis (i.e. a lower LAI). In 1996 (HI) and 1999 (HI and LI), sunflower growth was reduced by soil compaction resulting in fPARi less than $85 \%$.

The absence of fungicide application in HI_unsprayed resulted in the highest rates of infected stems (75-85\% of girdling lesions) and severe yield losses (870 kg/ha in 1997 and $920 \mathrm{~kg} / \mathrm{ha}$ in 2000). This was consistent with the function for yield reduction proposed by Pinochet [35], i.e. a loss of $200 \mathrm{~kg} / \mathrm{ha}$ per $15 \%$ of girdling lesions at the $20-25 \%$ grain moisture stage. Increasing the risk of attack by combining early sowing, high plant density, high $\mathrm{N}$ rates and irrigation justified the use of fungicide for controlling the disease (HI strategy). However, even with fungicides, in 1996, 1997 and 2000, the proportion of stems with girdling lesions was still above $15 \%$ after spraying, causing yield losses even in such an intensified system.

The extra yield resulting from the application of a fungicide in HI was extremely dependent on weather conditions and disease progress in summer. In 1999, for instance, yield loss due to the absence of fungicide in HI_unsprayed $(80 \mathrm{~kg} / \mathrm{ha})$ was less than the economic threshold for spraying (200 kg/ha). In 1995 and 1998, no unsprayed check plots were arranged in HI management, but in view of the weather and the result of the LI unsprayed treatment, high yield losses were unlikely. At regional levels, during the same period, yield losses were limited in unsprayed crops: 240 to $350 \mathrm{~kg} / \mathrm{ha}$ in 1996-2001 [24].

Reducing crop density and nitrogen rates under rainfed and unsprayed management (LI) decreased the proportion of stems infected by Phomopsis as compared with HI_unsprayed management but the decrease was not sufficient to justify the exclusion of fungicide treatment when weather conditions favored the disease: $46 \%$ of girdling lesions for LI vs. $75 \%$ for 
Table VIII. Results from the Integrated Cropping Systems (ICS) experiment of INRA-Auzeville (1995-2000). HI: high-input system (irrigated, sprayed), LI: low-input system (rainfed, unsprayed)._ls: late-sown sunflower, _unspr: no fungicide application.

\begin{tabular}{|c|c|c|c|c|c|c|c|}
\hline Year & Treatments & Fungicide & $\begin{array}{c}\text { fPARi } \\
(\%)\end{array}$ & $\begin{array}{l}\text { Total lesions } \\
\text { (\% stems) }\end{array}$ & $\begin{array}{l}\text { Girdling lesions } \\
\text { (\% stems) }\end{array}$ & $\begin{array}{c}\text { Achene } \\
\text { dry yield }\left(\mathrm{kg} \cdot \mathrm{ha}^{-1}\right)\end{array}$ & $\begin{array}{c}\text { Relative gross } \\
\text { margin }\end{array}$ \\
\hline 1995 & $\begin{array}{l}\text { HI } \\
\text { LI }\end{array}$ & $\begin{array}{l}\text { Yes } \\
\text { No }\end{array}$ & $\begin{array}{c}86(2)^{\mathrm{a}} \\
84.5(2.5)\end{array}$ & $\begin{array}{l}8.5(7) \\
4(4.5)\end{array}$ & $\begin{array}{ll}6.5 & (7) \\
1.5 & (3)\end{array}$ & $\begin{array}{l}3990(710) \\
3170(380)\end{array}$ & $\begin{array}{c}100 \\
94\end{array}$ \\
\hline 1996 & $\begin{array}{c}\text { HI } \\
\text { HI_unspr } \\
\text { LI_ls }\end{array}$ & $\begin{array}{l}\text { Yes } \\
\text { No } \\
\text { No }\end{array}$ & $\begin{array}{c}81(6.5) \\
b \\
84.5(3)\end{array}$ & $\begin{array}{c}19(12) \\
77.5(9.5) \\
2.5(4)\end{array}$ & $\begin{array}{r}18.5(12) \\
72.5(6.5) \\
1.5\end{array}$ & $\begin{array}{c}3690(270) \\
\mathrm{b} \\
3400(320)\end{array}$ & $\begin{array}{c}100 \\
b \\
116\end{array}$ \\
\hline 1997 & $\begin{array}{c}\text { HI } \\
\text { HI_unspr } \\
\text { LI }\end{array}$ & $\begin{array}{l}\text { Yes } \\
\text { No } \\
\text { No }\end{array}$ & $\begin{array}{cl}90 & (0.5) \\
& b \\
86 & (1.5)\end{array}$ & $\begin{array}{c}28.5(10.5) \\
85(7) \\
65(15)\end{array}$ & $\begin{array}{c}21(6) \\
75(7) \\
46(23)\end{array}$ & $\begin{array}{ll}3500 & (300) \\
2630 & (110) \\
2270 & (490)\end{array}$ & $\begin{array}{c}100 \\
69 \\
73\end{array}$ \\
\hline 1998 & $\begin{array}{l}\mathrm{HI} \\
\mathrm{LI}\end{array}$ & $\begin{array}{l}\text { Yes } \\
\text { No }\end{array}$ & $\begin{array}{ll}91 & (1.5) \\
89 & (1.5)\end{array}$ & $\begin{array}{c}1(2) \\
11(10.5)\end{array}$ & $\begin{array}{c}1(2) \\
5(6.5)\end{array}$ & $\begin{array}{l}3810(210) \\
3740(180)\end{array}$ & $\begin{array}{l}100 \\
129\end{array}$ \\
\hline 1999 & $\begin{array}{c}\text { HI } \\
\text { HI_unspr } \\
\text { LI }\end{array}$ & $\begin{array}{l}\text { Yes } \\
\text { No } \\
\text { No }\end{array}$ & $\begin{array}{c}83.5(3) \\
84(2) \\
82(2.5)\end{array}$ & $\begin{array}{c}3(2.5) \\
15.5(10) \\
13(12)\end{array}$ & $\begin{array}{c}0.5(1.5) \\
6.5(0) \\
5.5(10)\end{array}$ & $\begin{array}{l}3340(230) \\
3260(270) \\
3220(10)\end{array}$ & $\begin{array}{l}100 \\
103 \\
126\end{array}$ \\
\hline 2000 & $\begin{array}{c}\text { HI } \\
\text { HI_unspr } \\
\text { LI } \\
\text { LI_ls }\end{array}$ & $\begin{array}{l}\text { Yes } \\
\text { No } \\
\text { No } \\
\text { No }\end{array}$ & $\begin{aligned} 91 & (1) \\
90 & (2) \\
79.5 & (2.5) \\
86.5 & (2)\end{aligned}$ & $\begin{array}{c}68.5(19) \\
96.5(6) \\
86.5(7) \\
41.5(8)\end{array}$ & $\begin{array}{l}40(11) \\
85(10) \\
57.5(7) \\
31(10)\end{array}$ & $\begin{array}{cc}4180 & (180) \\
3260 & (30) \\
2850 & (100) \\
3300 & (260)\end{array}$ & $\begin{array}{c}100 \\
75 \\
78 \\
93\end{array}$ \\
\hline
\end{tabular}

No statistical comparisons were possible between the management options because the cropping system experiment was unreplicated. ${ }^{\text {a }}$ Standard deviation. ${ }^{\mathrm{b}}$ No data available.

HI_unsprayed in $1997,58 \%$ for LI vs. $85 \%$ for HI_unsprayed in 2000 .

Delaying sowing by 12 (2000) to 35 (1996) days in treatment LI was an alternative strategy to reduce the risk of Phomopsis infection. In 1996, $2 \%$ of girdling lesions were observed in LI (vs. 73\% in HI_unsprayed). In 2000, 31\% of girdling lesions were observed in LI (vs. $85 \%$ in HI_unsprayed) but sowing was not as delayed as previously.

In 1995, 1998 and 1999, the low infection level resulting from unfavorable weather (lack of rain in June, dry and hot in July) meant that there was no difference between the HI and LI management options and yield losses were always less than the economic threshold. In 1997 and 2000, better disease control was obtained by chemicals in HI_sprayed because crop rationing was not sufficient to hinder the development of Phomopsis in LI. In a wet spring, deferring sowing until the middle of May is the only non-chemical method to maintain the proportion of infected stems at a level close to what is possible with spraying.

\subsection{Choice of the most profitable strategy in Phomopsis-prone environments}

The gross margin was expressed relative to the high density and high nitrogen management option in each of the experiments based on a price of 17.5 Euros per $100 \mathrm{~kg}$ of commercial yield (Tabs. VI-VIII). When the level of infection was high because of the weather (1994 and 2000) or when inoculum pressure was increased, high-input management systems, including the use of a fungicide, generally resulted in the highest gross margin (INRA-94, ICS-97 and ICS-00), but reducing plant density and/or nitrogen fertilization was an alternative, especially when using susceptible genotypes (Cetiom-94, INRA-94, Cetiom-99I and Cetiom-00).

When the infection level was low, the economic response to fungicide was limited and the management systems that used a tolerant genotype and reduced inputs were the most profitable (ICS-98, ICS-99 and Cetiom-99S). However, when using short cultivars (such as cv. Santiago) under rainfed management, $\mathrm{N}$ fertilization and plant density should not be reduced too drastically in order to preserve a minimum yield level.

When practising delayed sowing with no fungicide (and tolerant genotypes), the values of the gross margin were slightly lower (ICS-00), equal (Cetiom-96) or higher (ICS-96) when compared with the strategy of early sowing and always using a fungicide.

\section{DISCUSSION AND CONCLUSIONS}

These experiments, covering a wide range of weather and cultural conditions, provided useful information about the field response of Phomopsis infection to sunflower crop management. The consistency of the results enables general conclusions to be drawn as to the effects of crop management.

The proportion of plants infected by Phomopsis increased at higher plant densities. This effect has been mentioned in the literature but never thoroughly explored or discussed [19, 26]. Our results provide strong evidence of this effect, which may have two causes. Firstly, canopy closure is more rapid in dense stands, creating conditions of high relative humidity which make leaf infection more likely $[10,36]$; this should result in early infection and a higher proportion of stems with girdling lesions or total senescence 3-4 weeks before physiological 
maturity. Secondly, dense crops are characterized by small leaves and thin stems which could be more rapidly destroyed by Phomopsis, causing plant wilting and stem breakage. The effect of crop density is especially important in growing seasons where early infection and isolated rainy events occurred. In such conditions, the degree of canopy closure during the early stages of flower bud is the main factor limiting successful leaf infection. Crop density has less influence during later attacks because the differences in leaf area index and microclimatic conditions between high and low plant densities decrease with time $[10,11]$. In addition, as natural leaf senescence is accelerated in dense stands because of the low PAR penetration deep into the canopy and because of early water depletion under rainfed management, the progression of the mycelium towards the stem could be hindered by leaf senescence more than in a more open stand. The influence of crop density was also limited in frequently irrigated canopies where inoculum was continuously available and where the relative humidity was high enough for infection even within the most open stands (for instance, INRA-00I).

The effect of nitrogen fertilization (and of $\mathrm{N}$ status generally) on the proportion of stems attacked by Phomopsis was not clear-cut. As for the effect of crop density, rapid canopy closure occurred with the highest amounts of $\mathrm{N}$ applied at sowing time through an increase in individual leaf area for a given plant density [3]. It resulted, in most cases, in an increase in the proportion of stems infected by Phomopsis, although the effect was less pronounced than with crop density (Cetiom-99 and INRA-99). In the same way, an increase in stem attacks in highly fertilized sunflower was reported by Jinga et al. [23]. More generally, increasing $\mathrm{N}$ and $\mathrm{P}$ rates are reported to favor Phomopsis occurrence and damage, while increasing $\mathrm{K}$ reduced the level of attack [21]. Conversely, in several independent experiments (Cetiom-00 and INRA-00), more symptoms were observed on leaves and stems without fertilizer input (Fig. 4). We suggest that with natural infection, which occurs mainly in May and June, highly fertilized crops are more likely to be successfully infected on leaves than lowfertilized crops, because $\mathrm{N}$ deficiency during this period may be critical in terms of leaf area index and the resulting microclimate within the canopy. Under semi-natural infection, the presence of infected stalks in the inter-row is a source of permanent inoculum for numerous infection events throughout the growing season. As the ascospores are splashed by frequent irrigation (or rain), we may assume that the distribution of the spores is more efficient in open canopies, resulting from $\mathrm{N}$ deficiency. The shorter laminae and petioles in such canopies could hasten the spread of the mycelium towards the axil. A similar observation was reported by Estragnat (personal communication) in 1992 when a sunflower crop was exposed to excessive rainfall in June (17 rainy days), which resulted in a severe nitrogen stress. In this experiment, $30 \%$ of the stems were infected at the end of the season on no-nitrogen plots compared with $5 \%$ on plots receiving $120 \mathrm{~kg} \mathrm{~N} / \mathrm{ha}$. The hypothesis of a greater receptivity of N-deficient crops to Phomopsis attack cannot be discussed without an appraisal of $\mathrm{N}$ deficiency (for instance, the Nitrogen Nutrition Index or leaf nitrogen). Only studies on isolated plants could help to separate the influence of nitrogen on the microclimate from the intrinsic susceptibility of plant tissue.
Increasing the $\mathrm{N}$ rate generally results in more sunflower plants infected by Alternaria helianthi, Macrophomina phaseolina, Phoma macdonaldii and Sclerotinia sclerotiorum [9, 20]. Phoma and Phomopsis are competing for axil infection. As Phoma infection predominantly starts from the petiole groove, this pathogen may have an advantage over Phomopsis for stem colonization, the rapid leaf senescence stopping the progression of Phomopsis towards the axil. As Phoma is clearly stimulated by nitrogen [9], this could result in a lower proportion of stems infected by Phomopsis in highly fertilized crops. But in 1999 and 2000, as Phoma was selectively controlled by mancozeb, it could not have obstructed the spread of Phomopsis.

According to several authors [16, 20, 23, 33] early sowing usually results in the most severe infection. In 1996 (ICS-1996 and Cetiom-1996) and 2000 (ICS-2000), we concluded that delayed sowing helped the crop to escape infection and justified omitting fungicidal treatment in such a situation. This effect could be attributed to the phenological stage at the time of infection: although infection is possible as long as green leaves are present, the highest proportion of stems with lesions was observed for plants infected at the earliest stages of budding, probably because more leaves can be infected at this period $[15,16,30]$. Late sowing generally reduces the number of successful infection events because of fewer rain events, a higher frequency of days with maximum temperature $>32{ }^{\circ} \mathrm{C}$ (Tab. IV), and a reduction in the duration of susceptible phases and of complete canopy closure, all resulting in a low proportion of stems with girdling lesions. When June and July are wet, which is rarely the case in Southwestern France, escaping rain events in these months by delaying sowing may be ineffective. This was suggested from the simulations with Asphodel for a range of weather patterns [12]. Escaping Phomopsis infection by delayed flowering was observed for a range of genotypes differing in the date of anthesis [18, 25]: early flowering genotypes were generally infected more than later ones.

A simple relation between the proportion of infected stems and the fraction of PAR intercepted at anthesis (or leaf area index) could be used for interpreting the effect of crop management on Phomopsis infection by separating canopy and weather effects (Fig. 6). A reference curve established for a moderately susceptible genotype was recently proposed [4]. Conditions favoring inoculum pressure (rainy season), plant receptivity (early sowing), and extension of leaf symptoms (late irrigation) combined with the use of susceptible genotypes should result in high infection levels exceeding the reference curve. Drought, late sowing, fungicide application and resistant genotypes should result in low infection levels below the reference curve. This model, which has already been applied to Phoma [9], could be used as a diagnostic tool in field surveys.

In regions where Phomopsis is frequently a limiting factor of achene yield and oil content in sunflower, the use of cultural methods aiming at disease escape and crop rationing is a profitable and sustainable way of reducing the use of fungicides, provided that tolerant or moderately susceptible genotypes are used at the same time. In conditions of heavy rainfall in late spring, cultural methods alone are insufficient to maintain the infection level below the economic threshold for spraying. 
Acknowledgements: This study was supported by a 3-yr grant from ONIOL (1998-2000). We are grateful to the technical staff of INRA (P. Bataillon, S. Cardeillac, D. Chesneau, R. Fuser and D. Raffaillac) and Cetiom (P. Cristante) for the setting-up and careful conduct of the experiments. J. Moinard from SRPV Midi-Pyrénées kindly helped us to interpret the outputs of the Asphodel model. Several students participated actively in the measurements (S. Berault, C. Cappelleto, J. Chabanis and S. Piasentin). We thank them all once more for their kind and useful help.

\section{REFERENCES}

[1] Acimovic M., The effect of Phomopsis sp. infection on grain yield and oil content of sunflower plants, Helia 9 (1986) 73-76.

[2] Acimovic M., Straser N., Phomopsis sp. - a new parasite in sunflower, Helia 4 (1981) 43-58.

[3] Blanchet R., Gelfi N., Puech J., Alimentation azotée, surface foliaire et formation du rendement du tournesol (Helianthus annuus L.), Agrochimica 31 (1987) 233-244.

[4] Debaeke P., A simple relation to interpret the occurrence of diseases in sunflower as a function of crop management, Proc. 7 th ESA Congress, Cordoba (Spain), 2002, pp. 259-260.

[5] Debaeke P., Raffaillac D., Light interception as an indicator of leaf area index and risk of diseases in sunflower, Helia 19 (1996) 1-15.

[6] Debaeke P., Jouffret P., Reau R., Le tournesol en France : surfaces, conduites et résultats, OCL 5 (1998) 86-91.

[7] Debaeke P., Cabelguenne M., Hilaire A., Raffaillac D., Crop management systems for rainfed and irrigated sunflowe (Helianthus annuus) in South-Western France, J. Agric. Sci. (Camb.) 131 (1998) 171-185.

[8] Debaeke P., Nolot J.M., Testing crop management systems for sunflower in South-West France, Proc. 15th Int. Sunflower Conf., Vol. 1, C, ISA, Toulouse (France), 2000, pp. 1-6.

[9] Debaeke P., Pérès A., Effets de la conduite de culture du tournesol sur l'expression de Phoma macdonaldii Boerema, Proc. 6th Int. Conf. Plant Diseases, AFPP, Tours (France), 2000, pp. 553-560.

[10] Debaeke P., Delos M., Moinard J., Bérault S., Lambert R., Prise en compte du couvert de tournesol dans la simulation des épidémies de Diaporthe helianthi par le modèle ASPHODEL, Proc. 6th Int. Conf. Plant Diseases, AFPP, Tours (France), 2000, pp. 251-258.

[11] Debaeke P., Estragnat A., Pérès A., Piasentin S., Recherche d'indicateurs du couvert pour la prévision précoce du risque phomopsis, Proc. 15th Int. Sunflower Conf., Vol. 1, C, ISA, Toulouse (France), 2000, pp. 38-43.

[12] Debaeke P., Delos M., Moinard J., Simulating the influence of sowing date on disease occurrence in sunflower, Proc. 2nd Int ESA Symp. Modelling Cropping Systems, Florence (Italy), 2001, pp. 123-124.

[13] Delos M., Moinard J., Évolution du Phomopsis du tournesol en France. Un bref historique, Phytoma 473 (1995) 22-24.

[14] Delos M., Moinard J., Jacquin D., Étude et surveillance du Phomopsis. Des pièges au modèle, Phytoma 473 (1995) 25-27.

[15] Delos M., Moinard J., ASPHODEL : Modèle de simulation des épidémies de Phomopsis du tournesol (Diaporthe helianthi), Med Fac. Landbouwwet. Univ. Gent 61/2b (1996) 555-565.

[16] Delos M., Moinard J., Phomopsis du tournesol : nouveaux progrès dans la prévision des épidémies, Phytoma 492 (1997) 17-21.

[17] Diaz Franco A., Ortegon Morales A., Influence of sunflower stem canker (Diaporthe helianthi) on seed quality and yield during seed development, Helia 20 (1997) 57-62.

[18] Fazekas M., Study of relationships between the time and intensity of sunflower flowering and infection rate of Phomopsis
(Diaporthe) helianthi Munt.-Cvet et al., Novenyvedelem 25 (1989) 158-162.

[19] Gheorghies C., Roman G.V., The effect of some crop production practices on diseases of sunflower on reddish-brown soil, Lucrari Stiintifice Institutul Agronomie «Nicolae Balescu» Bucaresti, Seria A, Agronomie 31 (1988) 73-79.

[20] Gulya T., Rashid K.Y., Masirevic S.M., Sunflower diseases, in: Schneiter A.A. (Ed.), Sunflower Technology and Production, Agronomy Monograph $\mathrm{N}^{\circ} 35$, ASA, CSSA, SSSA, Madison, WI (USA), 1997, pp. 263-379.

[21] Iliescu H., Baicu T., Mesures de lutte intégrée contre les agents pathogènes du tournesol, Helia 7 (1984) 39-42.

[22] Jinga V., Iliescu H., Rafaila C., Ciurea A., Ionita A., Csep N., Investigations on forecasting the attack of brown spot and stem canker (Diaporthe-Phomopsis) in sunflower, Analele Institutului de Cercetari Pentru, Prot. Plant. 20 (1987) 57-68.

[23] Jinga V., Iliescu H., Ionita A., Csep N., Iordache E., Technological factors in the integrated control of sunflower diseases, Proc. 13th Int. Sunflower Conf., ISA, Pisa (Italy), 1992, pp. 761-765.

[24] Lecomte V., Wagner D., Bilan de l'enquête 2001 sur les pratiques culturales en tournesol dans le Sud-Ouest, Cetiom, Zone Sud, 2002, 8 p.

[25] Leterme P., Phomopsis et Sclerotinia feuilles/bouton : des essais non spécifiques, Oléoscope 10 (1992) 8-10.

[26] Masirevic S., Gulya T.J., Sclerotinia and Phomopsis - two devastating sunflower pathogens, Field Crop. Res. 30 (1992) 271-300.

[27] Masirevic S., Forgic G., Sunflower diseases - limiting factor in sunflower production, Rev. Agron. Saznanja 10 (2000) 46-50.

[28] Muntanola-Cvetkovic M., Mihaljcevic M., Petrov M., On the identity of the causative agent of a serious Phomopsis-Diaporthe disease in sunflower plants, Nova Hedwigia 34 (1981) 417-435.

[29] Muntanola-Cvetkovic M., Vukojevic J., Mihaljcevic M., Pathohistology of sunflower stems attacked by Diaporthe helianthi, Can. J. Bot. 67 (1989) 1119-1125.

[30] Penaud A., Pérès A., Regnault Y., Rappels sur la maladie, Oléoscope $N^{\circ}$ Spécial 14 (1995) 15-26.

[31] Penaud A., Jouffret P., Phomopsis du tournesol : la lutte fongicide se raisonne, Oléoscope 33 (1996) 27-29.

[32] Pérès A., Regnault Y., Diaporthe helianthi Munt.Cvet. et al. : Éléments de biologie et d'épidémiologie appliqués aux essais de lutte, Proc. 12th Int. Sunflower Conf., Vol. II, ISA, Novi-Sad (Yugoslavia), 1988, pp. 90-95.

[33] Perny A., Lagarde F., Jouffret P., Deverchère J., Campagnes 1993 et 1994 : vers une extension de la maladie, Oléoscope $\mathrm{N}^{\circ}$ Spécial 14 ( 1995) 7-15

[34] Picq G., Rayonnement solaire intercepté par les couverts des cultures de tournesol, facteur explicatif de la production, Proc. 12th Int. Sunflower Conf., ISA, Novi-Sad (Yugoslavia), 1988, pp. 81-85.

[35] Pinochet X., Phomopsis et évaluation variétale de la sensibilité, Oléoscope $\mathrm{N}^{\circ}$ Spécial 14 (1995) 27-36.

[36] Stanojevic D., Relationship between stand density and microclimate and their effect on some characters of sunflower, Proc. 11th Int. Sunflower Conf., ISA, Mar del Plata (Argentina), 1985, pp. 301-306.

[37] Viguié A., Serre F., Walser P., Vear F., Tourvieille de Labrouhe D., The use of natural infections under controlled conditions and of artificial infections to estimate Phomopsis resistance of sunflower hybrids: conclusions after ten years of trials, Proc. 15th Int Sunflower Conf., Vol.II, K, ISA, Toulouse (France), 2000, pp. 78-83. 